\title{
The inhibitive action of aniline on the autoxidation of sodium sulfite in acidic medium
}

\section{Abstract}

The kinetics of atmospheric autoxidation of S (IV) by $\mathrm{Ag}(\mathrm{I})$ at $\mathrm{pH} 4.02-5.25$ has been studied. The aqueous phase autoxidation of S (IV) is the major factor responsible for acidification of atmospheric aqueous system. The role of Aniline act as an inhibitor of $\mathrm{Ag}(\mathrm{I})$ catalysed autoxidation of S(IV) in acidic medium has been identified, and based on the observed results following rate law given and a free radical mechanism has been proposed.

$$
d[S(l V)] / d t=\left(k_{1}+k_{2}[A g(I)]\right)[S(l V)] / 1+B[\text { Aniline }]
$$

Experiments were carried out at $30 \leq \mathrm{T}^{\circ} \mathrm{C} \leq 40, \quad 4.02 \leq \mathrm{pH} \leq 5.25, \quad 1 \times 10^{-3} \mathrm{~mol} / \mathrm{cm}^{3} \leq$ $\left[\mathrm{S}(\mathrm{IV}) \leq 10 \times 10^{-3} \quad \mathrm{~mol} / \mathrm{cm}^{3}, \quad 5 \times 10^{-6} \mathrm{~mol} / \mathrm{cm}^{3} \leq[\mathrm{Ag}(\mathrm{I})] \leq 2.5 \times 10^{-5} \mathrm{~mol} / \mathrm{cm}^{3}, \quad 5 \times 10^{-7} \mathrm{~mol} /\right.$ $\mathrm{cm}^{3} \leq[$ Aniline $] \leq 8 \times 10^{-3} \mathrm{~mol} / \mathrm{cm}^{3}$. Based on the experimental results, rate constants and orders of the reactions were determined. The reaction order in S(IV) were first order for both reactions in the presence and absence of Aniline. The effect of $\mathrm{Ag}(\mathrm{I})$ ion and Aniline concentrations as well as an initial $\mathrm{pH}$ of the solution on the $\mathrm{S}(\mathrm{IV})$ oxidation rate were discussed. It was found that the rate of the $\mathrm{S}$ (IV) oxidation depends on the initial $\mathrm{pH}$ of the solution but it is independent of the $\mathrm{pH}$ change during the reaction. Addition of Aniline leads to the introduction of an induction period and decrease in reaction rate, most likely due to $\mathrm{SO}_{4}^{-1}$ radicals. The value of apparent energy and inhibition constant $\mathrm{B}$ were calculated in the presence of Aniline found as $26.43 \mathrm{KJ} \mathrm{mol}^{-1}$ and $0.26 \times 10^{3} \mathrm{~mol} \mathrm{dm}^{-3}$ respectively.
Volume 4 Issue I - 2017

\author{
Arun Kumar Sharma, Parashar P, Prasad \\ DSN, Rashmi Sharma \\ 'Department of Chemistry, Govt P.G. College Jhalawar-32600I, \\ Rajasthan, India \\ ${ }^{2}$ Department of Chemistry, S.P.C. Govt. College Ajmer-30500I, \\ Rajasthan, India
}

\begin{abstract}
Correspondence: Arun Kumar Sharma, Department of Chemistry, Govt. P.G. College , Jhalawar, 32600I, Rajasthan, India, Email sharmaaun423@gmail.com
\end{abstract}

Received: December 05, 2016 | Published: January 19, 2017

Keywords: kinetics, autoxidation, s(iv), ag(i), catalysis, inhibition, aniline, oxidation, concentrations

\section{Introduction}

Although the $\mathrm{SO}_{2}$ oxidation by $\mathrm{O}_{2}$ has been the subject of many studies, the mechanism of the reaction is far for settled. Both non radical and radical mechanism have been proposed. The atmospheric oxidation of $\mathrm{SO}_{2}$ by $\mathrm{O}_{2}$ in aqueous media has been the subject of numerous studies, and the subject matter of several reviews, monographs and papers, notably by Kuo et al., ${ }^{1-11}$ It is interesting to point out that reaction is strongly inhibited by alcohol, benzene, and other compounds. Pointing to the participation of radical intermediates. ${ }^{12-17}$ Bigelow ${ }^{18}$ was the first to observe the inhibiting effect of alcohols such as methanol, ethanol, propanol, butanol on the rate of the reaction between sodium sulfite and oxygen. The inhibiting effect of alcohols was investigated subsequently by Alyea et al., ${ }^{19}$ The other Organics studied are phenols ${ }^{20}$ organic acids, ${ }^{21-23}$ benzene, ${ }^{24}$ toluene, naphthalene, paraffin oil, ${ }^{25}$ alpha-pinene, cis - verbenol, ${ }^{26}$ sobrerol, ${ }^{27}$ myrtenol. ${ }^{28}$ The effect of aromatic amines i.e. aniline in atmospheric water on the transition metal-catalysed oxidation of S(IV) is not fully known yet and more work in this area is needed to understand these processes better. The purpose of the present study was to study the kinetics of the $\mathrm{Ag}(\mathrm{I})$ catalysed S(IV) oxidation and to determine the inhibiting effect of aniline on this process under different experimental conditions.

\section{Experimental}

The experimental procedure was exactly the same as described earlier. ${ }^{29}$ All the chemicals used were AR grade and their solutions were prepared in doubly distilled water. The reaction were conducted in $0.15 \mathrm{~L}$ Erlenmeyer flask, open to air and follow to passage of atmosphere oxygen. The flask was placed in a beaker which had an inlet at a lower part and an outlet at a outer part for circulating thermostatic water for maintaining the desired temperature $30+10 \mathrm{C}$. The reaction was initiated by adding the desired volume of $\mathrm{Na}_{2} \mathrm{~S}_{3}$ solution to the reaction mixture containing other additive such as buffer and catalyst. The reaction mixture was stirred continuously and magnetically at $1600+10 \mathrm{rpm}$ to allow the passage of atmospheric oxygen and to save the reaction from becoming oxygen mass transfer controlled. The kinetics was studied in acetate buffered medium in which the $\mathrm{pH}$ remained fixed throughout the entire course of reaction. For this purpose $10 \mathrm{~cm}^{3}$ buffer made from sodium acetate $(0.07 \mathrm{~mol}$ $\left.\mathrm{L}^{-1}\right)$ and acetic acid $\left(0.03 \mathrm{~mol} \mathrm{~L}^{-1}\right)$ for acidic medium were used (total volume $100 \mathrm{~cm}^{3}$ ) for obtaining the desired $\mathrm{pH}$. The kinetics were followed by withdrawing the aliquot samples periodically and titrating the unreacted S(IV) iodometrically. The reproducibility of replicate measurements was generally better than $10+1 \%$. All calculations were performed in MS Excel.

\section{Product analysis}

The qualitative test shows sulphate to be only oxidation product. For quantitative analysis, the reaction mixture containing catalyst and S(IV) in appropriate buffered solutions were constantly stirred for a sufficiently long time so as to ensure complete oxidation of S(IV). When the reaction was complete then $\mathrm{S}(\mathrm{VI})$ estimated gravimetrically by precipitating sulphate ions as $\mathrm{BaSO}_{4}$ using standard procedure.

The product analysis showed the recovery of sulphate to be $98+1 \%$, in all cases in agreement with eq. (1)

$$
S(I V)+0.5 \mathrm{O}_{2} \rightarrow S(V I)
$$




\section{Results}

\section{Preliminary investigation}

The kinetics of both uncatalysed and $\operatorname{Ag}(\mathrm{I})$ catalysed and aniline inhibited reaction were studied in acidic medium in $\mathrm{pH} 4.95$ and temperature $30^{\circ} \mathrm{C}$. In both the cases the first order dependence of S(IV) was observed in the kinetics data treatment for the determination of first order rate constant $k_{1}$ was carried out from $\log$ [S(IV)] versus time, t. The plots were shown in Figure 1 It is obs. from Figure 1 that both the uncatalysed and $\mathrm{Ag}(\mathrm{I})$ catalysed autoxidation of S(IV) reaction are inhibited by aniline.

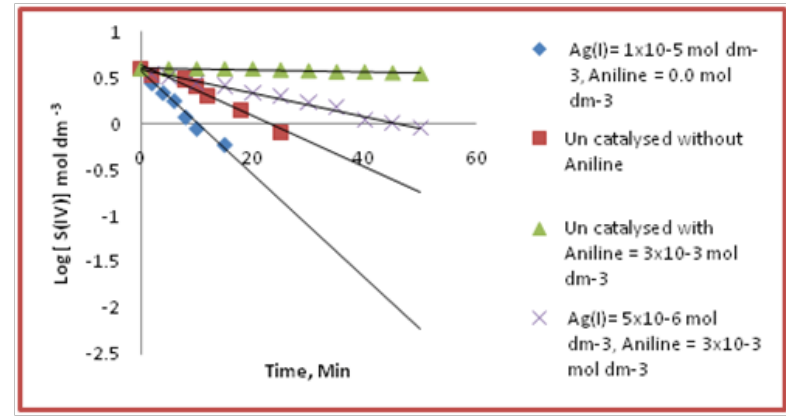

Figure I The disappearance of $[\mathrm{S}(\mathrm{IV})]$ with time in air saturated suspensions at $[\mathrm{S}(\mathrm{IV})]=2 \times 10^{-3} \mathrm{~mol} \mathrm{dm}^{-3}$ at $\mathrm{pH}=4.95, \mathrm{t}=30^{\circ} \mathrm{C}$.

$\diamond \mathrm{Ag}(\mathrm{I})=\mathrm{I} \times 10^{-5} \mathrm{~mol} \mathrm{dm}^{-3}$, [Aniline $]=0.0 \mathrm{~mol} \mathrm{dm}^{-3}$.

$\square$ Uncatalysed without aniline.

$\triangle$ Uncatalysed with $[$ Aniline $]=3 \times 10^{-3} \mathrm{~mol} \mathrm{dm}^{-3}$.

$\times A g(I)=5 \times 10^{-6} \mathrm{~mol} \mathrm{dm}^{-3},[$ Aniline $]=3 \times 10^{-3} \mathrm{~mol} \mathrm{dm}^{-3}$.

\section{Uncatalysed reaction}

Uncatalysed reaction was studied in the absence of $\operatorname{Ag}(\mathrm{I})$ and all the solutions were prepared in doubly distilled water.

\section{Dependence of S(IV)}

The detail dependence of the reaction rate on [S(IV)] was studied by varying it is in the range $1 \times 10^{-3} \mathrm{~mol} \mathrm{dm}^{-3}$ to $4 \times 10^{-3} \mathrm{~mol} \mathrm{dm}^{-3}$ at $\mathrm{pH}$ $=4.95, \mathrm{t}=30^{\circ} \mathrm{C}$ in acetate buffered medium. The kinetics was found to be first order in [S(IV)] and values of $\mathrm{K}_{1}$ was calculated from $\log$ [S(IV)] v/s time plots which was linear. The values of first order rate constant $\mathrm{K}_{1}$ are given in Table 1 . The dependence of reaction rate on [S(IV)] follows the rate law (2).

$$
-d[S(I V)] / d t=k_{1}[S(I V)]
$$

Table I The values of $K_{1}$ for uncatalysed reaction at different [S(IV)], $\mathrm{pH}=$ $4.95, \mathrm{t}=30^{\circ} \mathrm{C}, \mathrm{CH} 3 \mathrm{COONa}=7 \times 10^{-2} \mathrm{~mol} \mathrm{~L}^{-1}, \mathrm{CH} 3 \mathrm{COOH}=3 \times 10^{-2} \mathrm{~mol} \mathrm{~L}^{-1}$

\begin{tabular}{ll}
\hline$[S(I V)] ~ m o l ~ d m-3$ & $($ I 03) KI s-I \\
\hline $0.00 I$ & 1.04 \\
\hline 0.002 & 1.06 \\
\hline 0.003 & 1.09 \\
\hline 0.004 & 1.09 \\
\hline
\end{tabular}

\section{[Aniline] dependence}

The major aim of this study was to examine the effect of aniline on the autoxidation of S(IV) in acetate buffer medium and varying the [aniline] from $5 \times 10-7 \mathrm{~mol} \mathrm{dm}^{-3}$ to $8 \times 10^{-3} \mathrm{~mol} \mathrm{dm}^{-3}$, we observed the rate of thereaction decreased by increasing [aniline] The results are given in Table 2 However the nature of the [S(IV)] dependence in presence of aniline did not change and remains first order. The first order rate constant $\mathrm{K}_{\mathrm{inh}}$ in the presence of anilinewas defined by rate law (3).

$$
-d[S(I V)] / d t=k_{i n h}[S(I V)]
$$

Table 2 The values of $\mathrm{K}_{\text {inh }}$ at different [Aniline], $\mathrm{pH}=4.95, \mathrm{t}=30^{\circ} \mathrm{C}$ $\mathrm{CH} 3 \mathrm{COONa}=7 \times 10^{-2} \mathrm{~mol} \mathrm{~L}^{-1} \mathrm{CH} 3 \mathrm{COOH}=3 \times 10^{-2} \mathrm{~mol} \mathrm{~L}^{-1}$

\begin{tabular}{lll}
\hline [Aniline] mol dm-3 & I03 Kinh s-I & I/Kinh s \\
\hline $5.0 \times 10-7$ & 0.94 & 1064 \\
$5.0 \times 10-6$ & 0.827 & 1209 \\
$8.0 \times 10-6$ & 0.707 & 1414 \\
$1.0 \times 10-5$ & 0.607 & 1647 \\
$5.0 \times 10-5$ & 0.513 & 1949 \\
$8.0 \times 10-5$ & 0.418 & 2392 \\
$1.0 \times 10-4$ & 0.36 & 2778 \\
$5.0 \times 10-4$ & 0.284 & 3521 \\
$8.0 \times 10-4$ & 0.189 & 5291 \\
$3.0 \times 10-3$ & 0.138 & 7246 \\
$5.0 \times 10-3$ & 0.075 & 13333 \\
$8.0 \times 10-3$ & 0.037 & 27027 \\
\hline
\end{tabular}

The values of $\mathrm{K}_{\text {inh }}$ in the presence of aniline decreased with increasing [Aniline] are given in Table 2 which are in agreement with the rate law (4).

$$
k_{\text {inh }}=k_{1} /(1+B[\text { aniline }])
$$

Where B is inhibition parameter for rate inhibition by aniline. The equation (4) on rearrangement becomes

$$
1 / k_{\text {inh }}=1 / k_{1}+B[\text { aniline }] / k_{1}
$$

In accordance with the equation (5) the plot of $1 / \mathrm{K}_{\text {inh }} \mathrm{v} / \mathrm{s}$ [aniline] was found to be linear with non- zero intercept. The values of intercept $\left(1 / \mathrm{K}_{1}\right)$ and slope $\left(\mathrm{B} / \mathrm{K}_{1}\right)$ were found to be $1.53 \times 103 \mathrm{~s}$ and $2.86 \times 106$ mol dm ${ }^{-3} \mathrm{~s}$ at $\mathrm{pH}=4.95, \mathrm{t}=30^{\circ} \mathrm{C}$ From these values the value of inhibition parameter B was found to be $1.86 \mathrm{x} 103 \mathrm{~mol} \mathrm{dm}^{-3}$.

\section{$\mathrm{Ag}(\mathrm{I})$ catalysed reaction}

At first the kinetics of $\mathrm{Ag}(\mathrm{I})$ Catalysed reaction in the absence of inhibitor was studied.

\section{[S(IV)] variation}

The dependence of S (IV) on reaction rate was studied by varying [S(IV)] from $1 \times 10^{-3} \mathrm{~mol} \mathrm{dm} \mathrm{dm}^{-3}$ to $10 \times 10^{-3} \mathrm{~mol} \mathrm{dm}^{-3}$ at two different but fixed $\mathrm{Ag}(\mathrm{I})$ of $5 \times 10^{-6} \mathrm{~mol} \mathrm{dm}^{-3}$ and $1 \times 10^{-5} \mathrm{~mol} \mathrm{dm}^{-3}$ at $\mathrm{pH}=4.95, \mathrm{t}=$ $30^{\circ} \mathrm{C}$ The kinetics was found to be first order in [S(IV)] v/s time were linear as shown in Figure 1.

\section{$\mathrm{Ag}(\mathrm{I})$ variations}

The dependence of $\mathrm{Ag}(\mathrm{I})$ on the reaction rate was studied by varying $\mathrm{Ag}$ (I) from $5 \times 10^{-6} \mathrm{~mol} \mathrm{dm} \mathrm{dm}^{-3}$ to $2.5 \times 10^{-5} \mathrm{moldm}^{-3}$ at $\mathrm{S}(\mathrm{IV})=2 \times 10^{-3} \mathrm{~mol}$ $\mathrm{dm}^{-3} \mathrm{pH}=4.95, \mathrm{t}=30^{\circ} \mathrm{C}$ in acetate buffer medium. The values of First order rate constant kcat for $\mathrm{S}(\mathrm{IV})$ oxidation was determine are shown in Figure 2. The nature of dependence of kcat on $\mathrm{Ag}$ (I) was indicated as two term rate law (6).

$$
\begin{aligned}
& -d[S(I V)] / d t=k_{c a t}[S(I V)]=\left(k_{1}+k_{2}[A g(I)][S(I V)]^{(6)}\right. \\
& \text { Or } k_{c a t}=k_{1}+k[A g(I)] \text { (7) }
\end{aligned}
$$


From the plot in Figure 2 the values of intercept is equal to $\mathrm{K}_{1}$ and slope is equal to $\mathrm{k} 2$ were found to be $0.72 \times 101 \mathrm{~s}$ and $8.6 \times 10^{-3} \mathrm{~mol}$ $\mathrm{dm}^{-3} \mathrm{~s}$ respectively at $\mathrm{pH}=4.95, \mathrm{t}=30^{\circ} \mathrm{C}$ in acetate buffered medium.

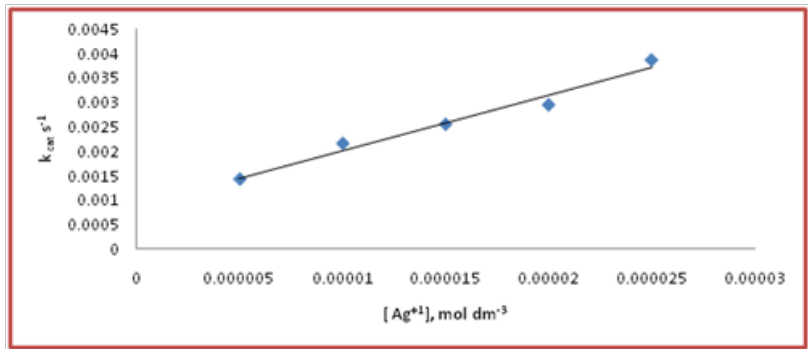

Figure 2 The dependence of catalyst concentration at $[\mathrm{S}(\mathrm{IV})]=2 \times 10^{-3} \mathrm{~mol}$ $\mathrm{dm}^{-3}, \mathrm{pH}=4.95, \mathrm{t}=30^{\circ} \mathrm{C}$ in acetate buffered medium.

\section{Variation of $\mathrm{pH}$}

Variation of $\mathrm{pH}$ was carried out from 4.02- 5.25 at different [S (IV), Ag (I), [Aniline] and temperatures. The rate decreases slightly by varying $\mathrm{pH}$ is inverse $\mathrm{H}+$ ion dependence was observed. From the plot of $\log \mathrm{K}_{1} \mathrm{v} / \mathrm{s} \log (\mathrm{H}+)$ the order with respect to $\mathrm{H}+$ is 0.16 which is a fractional order and can be neglected as shown in Figure 3 (Table $3 \& 4)$.

Table 3 Rate of $\mathrm{Ag}(\mathrm{I})$ catalysed autoxidation in the presence of Aniline

\begin{tabular}{|c|c|c|c|}
\hline $\begin{array}{l}\text { [Aniline], } \\
\text { mol dm-3 }\end{array}$ & $\begin{array}{l}\mathrm{Ag}(\mathrm{I})=5 \times 10- \\
6 \mathrm{~mol} \mathrm{dm}-3\end{array}$ & $\begin{array}{l}\mathrm{Ag}(\mathrm{I})=\mathrm{I} \times \mathrm{IO}- \\
5 \mathrm{~mol} \mathrm{dm}-3\end{array}$ & $\begin{array}{l}\mathrm{Ag}(\mathrm{I})=\mathrm{I} .5 \\
\times \quad 10-5\end{array}$ \\
\hline \multicolumn{4}{|l|}{$\mathrm{pH}=4.02$} \\
\hline $5.0 \times 10-4$ & $0.470 \times 10-3$ & $0.564 \times 10-3$ & $0.717 \times 10-3$ \\
\hline $8.0 \times 10-4$ & $0.400 \times 10-3$ & - & - \\
\hline $3.0 \times 10-3$ & $0.319 \times 10-3$ & 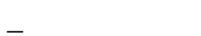 & _ \\
\hline \multicolumn{4}{|l|}{$\mathrm{pH}=4.50$} \\
\hline $5.0 \times 10-4$ & $0.499 \times 10-3$ & $0.590 \times 10-3$ & $0.788 \times 10-3$ \\
\hline $8.0 \times 10-4$ & $0.471 \times 10-3$ & - & - \\
\hline $3.0 \times 10-3$ & $0.402 \times 10-3$ & - & - \\
\hline \multicolumn{4}{|l|}{$\mathrm{pH}=5.25$} \\
\hline $5.0 \times 10-4$ & $0.586 \times 10-3$ & $0.718 \times 10-3$ & $0.942 \times 10-3$ \\
\hline $8.0 \times 10-4$ & $0.577 \times 10-3$ & - & _ \\
\hline $3.0 \times 10-3$ & $0.516 \times 10-3$ & _- & 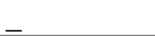 \\
\hline
\end{tabular}

Table 4 Ratio of rates for $\mathrm{Ag}$ (I) catalysed oxidation in the absence and in the presence of Aniline

\begin{tabular}{llll}
\hline $\begin{array}{l}{[A n i l i n e] 5.0} \\
\times 10-4 \mathrm{~mol}\end{array}$ & $\begin{array}{l}\mathrm{Ag}(\mathrm{I}) \\
=5 \times 10- \\
\mathbf{6 m}-3\end{array}$ & $\begin{array}{l}\mathrm{Ag}(\mathrm{I})=\mathrm{I} \\
\times 10-5 \mathrm{~mol} \text { m-3 } \\
\mathrm{dm}-3\end{array}$ & $\begin{array}{l}\mathrm{Ag}(\mathrm{I})=\mathrm{I} .5 \\
\times 10-5 \mathrm{~mol} \\
\mathrm{dm}-3\end{array}$ \\
\hline $\mathrm{PH}=4.50$ & & & \\
\hline & 3.02 & 3.82 & 3.54 \\
\hline
\end{tabular}

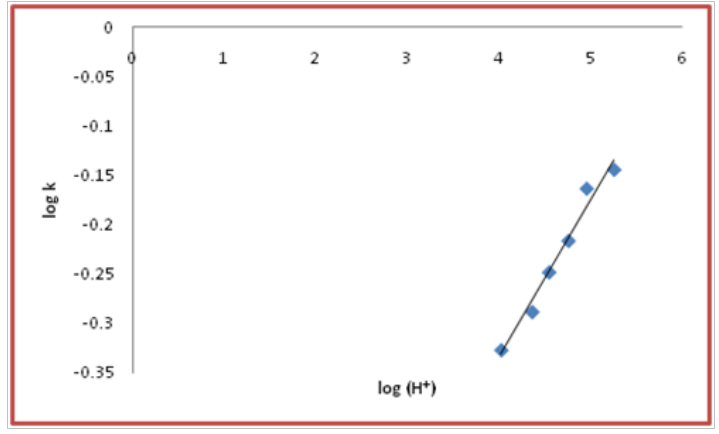

Figure 3 Effect of $\mathrm{pH}$ at $[\mathrm{S}(\mathrm{IV})]=2 \times 10^{-3} \mathrm{~mol} \mathrm{dm}^{-3}, \mathrm{Ag}(\mathrm{I})=5 \times 10^{-6} \mathrm{~mol} \mathrm{dm}^{-3}$, [Aniline] $=5.0 \times 10^{-4} \mathrm{~mol} \mathrm{dm}^{-3}, \mathrm{t}=30^{\circ} \mathrm{C}$ in acetate buffered medium.

\section{[Aniline] dependence}

To know the effect of aniline on $\mathrm{Ag}(\mathrm{I})$ catalysed autoxidation of $\mathrm{S}(\mathrm{IV})$ aniline variation was carried out from $5 \times 10-7 \mathrm{~mol} \mathrm{dm}^{-3}$ to $3 \mathrm{x}$ $10^{-3} \mathrm{~mol} \mathrm{dm}^{-3}$ at two different $\mathrm{Ag}$ (I) that is $5 \times 10^{-6} \mathrm{~mol} \mathrm{dm}^{-3}$ to $1 \mathrm{x}$ $10^{-5} \mathrm{~mol} \mathrm{dm}^{-3}$ but fixed $\mathrm{S}(\mathrm{IV})=2 \times 10^{-3} \mathrm{~mol} \mathrm{dm}{ }^{-3}, \mathrm{pH}=4.95, \mathrm{t}=30^{\circ} \mathrm{C}$ The results indicated that by increasing aniline the rate becomes decelerates (Figure $4 \& 5$ ).

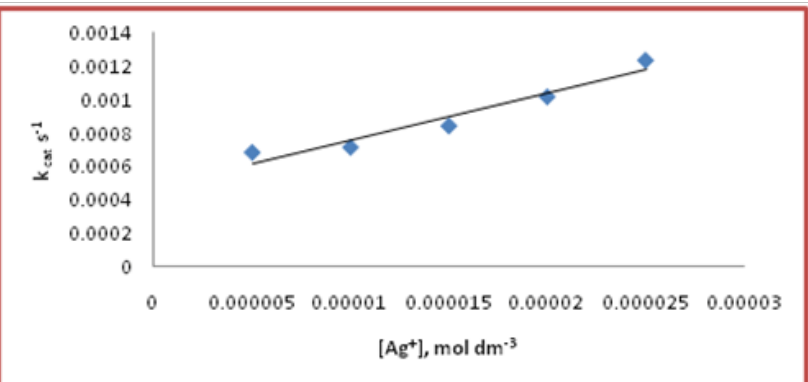

Figure 4 Effect of catalyst at $[\mathrm{S}(\mathrm{IV})]=2 \times 10^{-3} \mathrm{~mol} \mathrm{dm}^{-3},[$ Aniline $]=5.0 \times 10^{-4} \mathrm{~mol}$ $\mathrm{dm}^{-3}, \mathrm{t}=30^{\circ} \mathrm{C}$ in acetate buffered medium. The value of intercept and slope are $4.8 \times 10^{-4} \mathrm{~s}$ and $2.7 \times 101 \mathrm{~mol} \mathrm{dm}^{-3} \mathrm{~s}$ respectively. Depending on the observed results the reaction follows the following rate law (8).

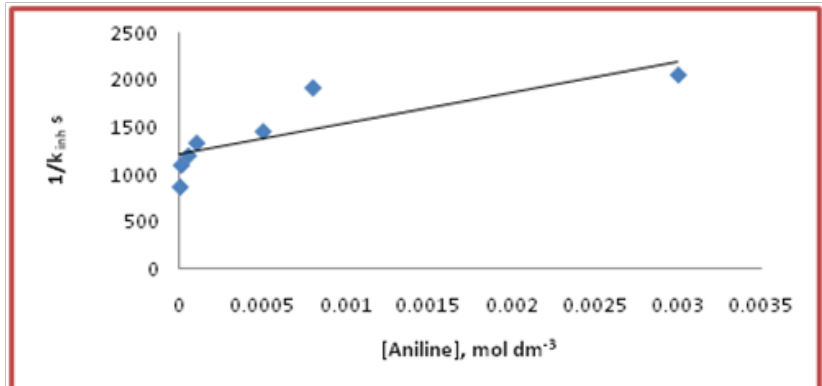

Figure 5 Effect of aniline at $[\mathrm{S}(\mathrm{IV})]=2 \times 10^{-3} \mathrm{~mol} \mathrm{dm}^{-3}, \mathrm{Ag}(\mathrm{I})=5 \times 10^{-6} \mathrm{~mol} \mathrm{dm}^{-3}$ $\mathrm{pH}=4.95, \mathrm{t}=30^{\circ} \mathrm{C}$ in acetate buffered medium. The plot of $\mathrm{I} / \mathrm{K}_{\text {inh }} \mathrm{v} / \mathrm{s}$ [Aniline] is linear with intercept $1.21 \times 10^{3} \mathrm{~s}$ and slope $3.25 \times 105 \mathrm{~mol} \mathrm{dm}^{-3} \mathrm{~s}$ from which the value of $B=0.26 \times 10^{3} \mathrm{~mol} \mathrm{dm}^{-3}$.

$$
-d[S(I V)] / d t=\left(k_{1}+k_{2}[A g(I)][S(I V)] / 1+B[\text { Aniline }]\right.
$$

Where

$$
\begin{gathered}
k_{\text {inh }}=\left(k_{1}+k_{2}[A g(I)] / 1+B[\text { Aniline }]=k_{\text {cat }} / 1+B[\text { Aniline }]\right. \\
1 / k_{\text {inh }}=1+B[\text { Aniline }] / k_{\text {cat }} \\
1 / k_{\text {inh }}=1 / k_{\text {cat }}+B[\text { Aniline }] / k_{\text {cat }}
\end{gathered}
$$

\section{Effect of temperature}

The values of kobs were determined at three different temperatures in the range of $30^{\circ} \mathrm{C}$ to $40^{\circ} \mathrm{C}$. The results are given in Table 5. By plotting a graph between $\log \mathrm{k}$ v/s $1 / \mathrm{T}$ yield us an apparent empirical energy of activation $26.43 \mathrm{KJ} \mathrm{moL}^{-1}$.

Table 5 Effect of temperature kobs air saturated suspensions at $[\mathrm{S}(\mathrm{IV})]=$ $2 \times 10^{-3} \mathrm{~mol} \mathrm{dm}^{-3}, \mathrm{Ag}(\mathrm{I})=5 \times 10^{-6} \mathrm{~mol} \mathrm{dm}^{-3},[$ Aniline $]=5.0 \times 10^{-4} \mathrm{~mol} \mathrm{dm}^{-3}, \mathrm{pH}$ $=4.95$

\begin{tabular}{ll}
\hline toC & I03 kobs S-I \\
\hline 30 & 0.686 \\
\hline 35 & 0.781 \\
\hline 40 & 0.915 \\
\hline
\end{tabular}




\section{Discussion}

In aqueous solutions $\mathrm{SO}_{2}$ is present in four forms $\mathrm{SO}_{2} \cdot \mathrm{H}_{2} \mathrm{O}, \mathrm{HSO}_{3}^{-1}$, $\mathrm{S}_{3}{ }^{-2}, \mathrm{~S}_{2} \mathrm{O}_{3}^{-2}$ In the experimental range of $\mathrm{pH}$ the following equilibrium operates

$$
\mathrm{HSO}_{3}^{-1} \mathrm{H}^{+} \rightleftharpoons+\mathrm{SO}_{3}^{-2}
$$

The equilibrium constant is $5.07 \mathrm{x} 10^{-7} \mathrm{In}$ the experimental range of $\mathrm{pH}$ both species $\mathrm{HSO}_{3}-1, \mathrm{SO}_{3}-2$ are present but former one present predominantly. During the course of reaction fraction order obtain is 0.18 indicates that it is almost independent of $\mathrm{pH}$ which is co-relate with the work of Irena. ${ }^{30}$ Prasad et al., ${ }^{31}$ studied the inhibiting effect of formic acid, ${ }^{31}$ isopropyl alcohol, ${ }^{32}$ isoamyl alcohol ${ }^{33}$ in the presence of $\operatorname{Ag}(\mathrm{I})$ catalysed autoxidation of S(IV) and reported the they all are influence the S(IV) oxidation in atmosphere with moderate rate. Gupta et al., ${ }^{34}$ studied the role of some organic organics on the oxidation of dissolved sulfur dioxide by oxygen in rain water medium and found it follows radical mechanism so free radical scavengers such as VOCs decelerate the S(IV) oxidation and control the rain water acidity. ${ }^{35}$ Bigelow et al., ${ }^{18}$ studied the effect of alcohols on the reactions between sodium sulphite and $0_{2}$ and found that the alcohols inhibited the reaction rate. Alyea et al., ${ }^{19}$ studied the inhibiting effect of aliphatic alcohols on sodium sulphite in alkaline medium. Gupta et al., ${ }^{34}$ studied the kinetics of environmentally important oxidation of $\mathrm{S}(\mathrm{IV})$ in acetate buffered medium in presence of Iron (III) in $\mathrm{pH}$ range 5.27- 5.70 and reported that addition of ethanol leads to decrease in reaction rate. Grgic et al., ${ }^{36}$ studied about scavenging of SO4- radical anions by mono and dicarboxylic acids in the $\mathrm{Mn}(\mathrm{II})$ catalysed oxidation in aqueous solutions and reported that low molecular weight carboxylic acids have low reactivity towards sulphate radical anion. Backstrom ${ }^{19}$ proposed a radical chain mechanism for alcohol inhibited oxidation reaction between sodium sulphite and $0_{2}$. Gupta et al studied the influence of hydroxyl VOCs on the oxidation of S(IV) by oxygen and found VOCs inhibited the S(IV) oxidation. Grgic et al. ${ }^{36}$ studied the inhibition effect of acetate, oxlate, format on $\mathrm{Fe}$ catalysed autoxidation of $\mathrm{S}(\mathrm{IV})$ at $\mathrm{pH} 2.8,3.7,4.5$ and found that oxlate has strong inhibiting effect on reaction rate due to the decrease amount of catalytic activity of $\mathrm{Fe}+3$ due to formation of complexion with oxlate. Bostjan et al., ${ }^{32}$ studied the effect of carboxylic acid on $\mathrm{Mn}$ (II) catalysed oxidation of S(IV) and found that monocarboxylic acid exhibit strong inhibition and out of which acetic acid shows strong inhibition. The rate of uncatalysed and $\mathrm{Ag}(\mathrm{I})$ catalysed reaction is decelerated by the addition of aniline in the present study. Gupta et al., ${ }^{37}$ reported that radical mechanism operate in those reaction in which the inhibition parameters lies $10^{3}-10^{4}$ In the present study the value of inhibition parameter for uncatalysed and $\operatorname{Ag}(\mathrm{I})$ catalysed autoxidation of S(IV) by anilineare found to be in the range $10^{3}$ $10^{4}$ These values are in the same range as reported by Gupta et al., ${ }^{37}$ This is strongly support the radical mechanism in the present case too based on the observed results. The free radical mechanism is very complex, the present work close to the experimental condition of Connick et al., ${ }^{38}$

By assuming long chain hypothesis and steady state approximation $\mathrm{d}\left[\mathrm{SO}_{3}\right] / \mathrm{dt}, \mathrm{d}\left[\mathrm{SO}_{4}\right] / \mathrm{dt}, \mathrm{d}\left[\mathrm{SO}_{5}\right] / \mathrm{dt}$, to zero. It can be shown that rate of initiation is equal to rate of termination (eq. 29).

Since the reaction is completely stopped in the presence of [Aniline] $=2 \times 10^{-4} \mathrm{~mol} \mathrm{dm}^{-3}$, so the step (22) and (25) appear to be unimportant. The step (24) is ignored because the reaction is completely seized in the presence of higher concentration of Aniline by omission and substitution from the above mechanism the following rate law can be obtain (30).

$$
\begin{aligned}
& \mathrm{HSO}_{3}{ }^{-1} \stackrel{k_{d}}{\rightleftharpoons} \mathrm{H}^{+}+\mathrm{SO}_{3}{ }^{-2} \mathrm{~K}_{d}=5.01 \times 10^{-7,18} \\
& \mathrm{Ag}^{+}+{ }^{-} \mathrm{O}_{2} \mathrm{CCH}_{3} \stackrel{\mathrm{K}_{\text {oAc }}}{\rightleftharpoons} \mathrm{AgO}_{2} \mathrm{CCH}_{3} \mathrm{~K}_{\text {oAdc }}=2.29^{33} \\
& \mathrm{Ag}^{+}+\mathrm{SO}_{3}^{-2} \stackrel{K_{1}}{\rightleftharpoons} \mathrm{AgOSO}_{2}^{-} K_{1}=2.51 \times 10^{5,29} \\
& \mathrm{Ag}^{+}+\mathrm{HSO}_{3}^{-1} \stackrel{\mathrm{K}_{2}}{\rightleftharpoons} \mathrm{AgHSO}_{3} \\
& \mathrm{AgOSO}_{2}^{-}+\mathrm{O}_{2} \stackrel{\mathrm{K}_{3}}{\rightleftharpoons} \mathrm{AgOSO}_{2}^{-1} \cdot \mathrm{O}_{2} \\
& \mathrm{AgHSO}_{3}+\mathrm{O}_{2} \stackrel{\mathrm{K}_{4}}{\rightleftharpoons} \mathrm{AgHSO}_{3} \mathrm{O}_{2} \\
& \mathrm{AgHSO}_{3} \mathrm{O}_{2} \stackrel{k_{1}}{\longrightarrow} \mathrm{Ag}^{+}+\mathrm{HSO}_{5}^{-} \\
& \mathrm{HSO}_{5}^{-}+\mathrm{HSO}_{3}^{-1} \stackrel{k_{2}}{\longrightarrow} \stackrel{-\bullet}{\mathrm{SO}_{4}}+\stackrel{-\bullet}{\mathrm{SO}_{3}}+\mathrm{H}_{2} \mathrm{O} \\
& \mathrm{AgOSO}_{2}^{-1} \cdot \mathrm{O}_{2} \stackrel{\mathrm{k}_{3}}{\longrightarrow} \mathrm{Ag}^{+}+\overrightarrow{\mathrm{SO}_{3+}} \mathrm{O}_{2} \\
& \mathrm{SO}_{3}+\mathrm{O}_{2} \stackrel{k_{4}}{\longrightarrow} \mathrm{SO}_{5} \\
& \mathrm{SO}_{5}+\mathrm{SO}_{3}{ }^{-2} \stackrel{k_{5}}{\longrightarrow} \stackrel{-\bullet}{\mathrm{SO}_{3}}+\mathrm{SO}_{5}^{-2} \\
& \mathrm{SO}_{5}+\stackrel{-}{\mathrm{SO}_{3}^{-2}} \stackrel{k_{6}}{\longrightarrow} \mathrm{SO}_{4}+\mathrm{SO}_{4}^{-2} \\
& \mathrm{SO}_{5}^{-2}+\mathrm{SO}_{3}^{-2} \stackrel{k_{7}}{\longrightarrow} 2 \mathrm{SO}_{4}^{-2}+\mathrm{SO}_{4}^{-2}
\end{aligned}
$$

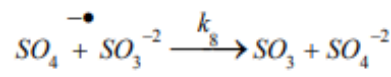

$$
\begin{aligned}
& \mathrm{SO}_{4}+x \stackrel{-}{\longrightarrow} \text { Non Chain product } \\
& \mathrm{SO}_{4}+\stackrel{-}{+} \text { sodium benzoate } \stackrel{{ }_{10}}{\longrightarrow} \text { Non Chain product } \\
& k_{1}\left[\mathrm{Ag}(\mathrm{I})\left(\mathrm{SO}_{3}^{-2}\right)\left(\mathrm{O}_{2}\right)\right]=\left\{k_{7}[\mathrm{X}]+k_{8}[\text { Aniline }]\right\}\left[\mathrm{SO}_{4}^{-1}\right] \\
& R_{\text {cat }}=k_{1}[A g(I)][S(I V)] /\left\{k_{9}[x]+k_{10}[\text { Aniline }]\right\}
\end{aligned}
$$

Prasad \& Gupta et al., ${ }^{11,37}$ proposed a similar mechanism for the $\mathrm{CO}_{2} \mathrm{O}_{3}$ and $\mathrm{CoO}$ catalysed autoxidation of $\mathrm{SO}_{2}$ inhibited by formic acid and ethanol respectively, which lead to the same rate law. By comparing derived rate law with the experimental rate law we observe the similarity in these two. The calculated value of inhibition constant $B$ is $1.86 \times 10^{3} \mathrm{~mol} \mathrm{dm}^{-3}$ which is in the range of $10^{3}-10^{4}$ and also coincide with the reported value of $\mathrm{B}$ of $\mathrm{CO}_{2} \mathrm{O}_{3}$ catalysed autoxidation of $\mathrm{S}(\mathrm{IV})$ by formic acid is $3.58 \times 10^{3} \mathrm{~mol} \mathrm{dm}^{-3}$. So on the basis of calculated value of $\mathrm{B}$ we concluded that Aniline act as an free radical scavenger in $\mathrm{Ag}(\mathrm{I})$ catalysed autoxidation of aqueous $\mathrm{S}_{2}$ in acidic medium and a free radical mechanism can operate in this system.

\section{Conclusion}

The following conclusions are deduced from the results of the Aniline inhibited $\operatorname{Ag}(\mathrm{I})$ catalysed autoxidation of S(IV) was that inhibit the oxidation with the fast influence. The value of inhibition factor of both uncatalysed and $\mathrm{Ag}(\mathrm{I})$ catalysed autoxidation of S(IV) in the present study are in the range of $10^{3}-10^{4}$ which shows that free radical mechanism is operative. 


\section{Acknowledgments}

None.

\section{Conflicts of interest}

Author declares there are no conflicts of interest.

\section{Funding}

None.

\section{References}

1. Kuo DTF, Krik DW, Jia CQ. The chemistry of aqueous S(IV)-Fe-O2 system: state of the art. Journal of Sulfur Chemistry. 2006;27(5):461-530.

2. Clemitshaw KC. Coupling between the trophospheric photochemistry of nitrous acid (HONO) and nitric acid (HNO3). Environmental Chemistry. 2006;3(1):31-34.

3. Brandt C, Van Eldik R. Transition metal-catalyzed oxidation of S(IV) oxides, Atmospheric relevant processes and mechanisms. Chemical Reviews. 1995;95(1):119-180.

4. Martin LR. Kinetic studies of sulphite oxidation in aqueous solution. In: Calvert JG (Eds.), Butterworth, Boston, USA. 1984.

5. Manoj SV, Mudgak PK, Gupta SK. Kinetic of iron(III) catalysed autoxidation of S(IV) in acetate buffered medium. Transition Metal Chemistry. 2008;33(3):3111-3316.

6. Huie RE, Peterson NC. Trace Atmospheric Constituents; Properties, Transformations \& Fates. In: Schwartz SE (Eds.), John Wiley and Sons, New York, USA. 1983. p.118-143.

7. Hoffmann MR, Boyce SD. Trace Atmospheric Constituents: Properties, Transformations and Fates. In: Schwartz SE (Eds.), John Wiley and Sons, New York, USA. 1983. p. 147-189.

8. Hoffman MR, Jacob DJ. SO2, NO and NO2 Oxidation Mechanisms. In: Calvert JG (Eds.), Atmospheric Considerations, Butterworth, Boston, USA. 1984. p.101-172.

9. Herrmann H. Kinetics of aqueous phase reactions relevant to atmospheric chemistry. Chemical Reviews. 2003;103(12):4691-4716.

10. Huie RE, Wayne Sieck L. S-Centered Radicals. In: Alfassi ZB (Eds.), John Wiley \& Sons, New York, USA. 1999. p.63-99.

11. Prasad DSN, Rani A, Gupta KS. Surface-Catalyzed oxidation of Sulfur(IV) in Aqueous silica and copper(II) oxide suspensions. Environmental Science and Technology. 1992;26(7):1361-1368.

12. Huss A, Lim PK, Eckert CA. On the 'uncatalyzed' oxidation of sulfur(IV) in aqueous solutions. Journal of American Chemistry Society. 1978;100(19):6252-6253.

13. Huss A, Lim PK, Eckert CA. Oxidation of aqueous sulfur dioxide. 1. Homogenous manganese (II) and iron (II) catalysis at low pH. Journal of Physical Chemistry. 1982; 86(21):4224-4228.

14. Huss A, Lim PK, Eckert CA. Oxidation of sulfur dioxide. 2. High pressure studies and proposed reaction mechanisms. Journal of Physical Chemistry. 1982;86(21):4229-4233.

15. Huss A, Lim PK, Eckert CA. Oxidation of sulfur dioxide. 3. The effects of chelating agents and phenolic antioxidants. Journal of Physical Chemistry. 1982;86(21):4233-4237.

16. Huie RE, Wayne Sieck L. S-Centered Radicals. In: Alfassi Z B (Eds.), John Wiley \& Sons, New York, USA. 1999. p.63-99. 10

17. Huie RE, Neta P. Chemical behaviour of SO3-and SO5-radicals in aqueous solutions. Journal of Physical Chemistry. 1984;88(23):5665-5669.

18. Bigelow SL. Catalytic effects in the oxidation of sodium sulfite by air oxygen. Zeitschriftfuer Physikalische Chemie. 1988;26:493-532.
19. Alyea HN, Backstrom HLJ. The inhibitive action of alcohols on the autoxidation of sodium sulfite. Journal of American Chemical Society. 1929;51(1):90-107.

20. Altwicker ER. Advances in Environmental Sciences and Engineering. In: Pfaffin JR \& Zieglar EN (Eds.), Gordon and Breach Science Publishers, New York, USA. 1980. p. 80-91.

21. Lee YJ, Rochelle GT. Oxidative degradation of organic acid conjugated with sulfite oxidation in flue gas desulfurization: products, kinetics and mechanism. Environ Sci Technol. 1987;21(3):266-271.

22. Grgic I, Dovzan A, Bercic G, et al. The effect of atmospheric organic compounds on the Fecatalyzed S(IV) autoxidation in aqueous solution. Journal of Atmospheric Chemistry. 1998;29(3):315-337.

23. Wolf A, Deutsch F, Hoffmann P, et al. The influence of oxalate on Fecatalyzed S(IV) oxidation by oxygen in aqueous solutions. Journal of Atmospheric Chemistry. 2000;37(2):125-135.

24. Ziajka J, Beer F, Warneck P. Iron-catalyzed oxidation of bisulfite aqueous solution: Evidence for a free radical chain mechanism. Atmospheric Environment. 1994;28(15):2549-2552.

25. Pasuik BW, Bronikowski T, Ulejczyk M. Solubilization of organics in water coupled with sulfite Autoxidation. Water Research. 1997;31(7):1767-1775.

26. Pasuik BW, Bronikowski T, Ulejczyk M. Chemical intractions of aqueous phase pollutants: Sulfur dioxide and sobrerol. In: Schurath U \& Roselieb R (Eds.), Aachen, Germany. 1998. p.1-4.

27. Pasuik BW, Bronikowski T, Ulejczyk M. Oscillations in the rate of S(IV) autoxidation inhibited by sobrerol. In: Vogt R \& Axelsdottir G (Eds.), Aachen, Germany. 1999. p.195-198.

28. Pasuik BW, Bronikowski T, Ulejczyk M. Transformation of atmospheric constituents and pollutants induced by S(IV) Autoxidation-Chemistry and kinetics. Chemical Mechanism Development. 2000. p.123-126.

29. Sameena B, Faiyaz H, Prasad DSN. Kinetics of formic acid inhibited uncatalysed and $\mathrm{Co} 2 \mathrm{O} 3$ catalysed autoxidation of $\mathrm{S}(\mathrm{IV})$ in alkaline medium. Pelagia research library. 2013; 4(1):122-131.

30. Irena W, Anna M. Mn(II) catalysed and its inhibition by acetic acid in aqueous solutions. Journal of Atmospheric Chemistry. 2008;60(1):1-17.

31. Arun KS, Parashar P, Gupta AK, et al. Formic Acid inhibited Ag (I) Catalysed Autoxidation of S(IV) in Acidic Medium. Journal of Chemistry and Chemical Sciences. 2015; 5(12):760-777.

32. Arun KS, Parashar P, Gupta AK, et al. Ag(I) catalysed autoxidation of S(IV) and its inhibition by Iso propyl alcohol in acidic medium. Chemical Sciences Review and Letters.2016;17(5):14-23.

33. Arun KS, Rashmi S, Prasad DSN. Kinetics and mechanism of uncatalysed and $\mathrm{Ag}$ (I) catalysed autoxidation of S(IV) and its inhibition by Iso amyl alcohol in acidic aqueous solutions. International Journal of Modern Sciences and Engineering Technology. 2015;2(12):31-40.

34. Yogpal D, Gupta KS. Role of some organic organicss on oxidation of SO2 in rain water medium. Environ Sci Pollut Res Int. 2014;21(5):3474 $-3483$.

35. Yogpal D, Gupta KS. The influence of hydroxyl organic compounds on the oxidation of $\mathrm{SO} 2$ by oxygen. Environ Sci Pollut Res Int. 2014;21(13):7808-7817.

36. Podkrajsek B, Grgic I, Tursic J, et al. Influence of atmospheric carboxylic acids on catalytic oxidation of sulfur(IV). Journal of Atmospheric Chemistry. 2006;54(2):103-120.

37. Gupta KS, Mehta RK, Sharma AK, et al. Kinetics of uninhibited and ethanol inhibited $\mathrm{CoO}, \mathrm{Co} 2 \mathrm{O} 3$ catalysed autoxidation of $\mathrm{S}(\mathrm{IV})$ in alkaline medium. Transition Metal Chemistry. 2008;33:809-817.

38. Connick RE, Zhang YX, Lee $\mathrm{S}$, et al. kinetics and mechanism of the oxidation of $\mathrm{HSO} 3$ by $\mathrm{O} 2$, the uncatalyzed reaction. Inorganic Chemistry. 1995;34(18):4543-4553. 